\title{
Změna teplot sněhu při běhu na lyžích v obraze sekvenční termografie
}

\section{Snow temperature change during cross-country skiing at moving thermography images}

\author{
Jan Novotný, Jan Ondráček, Jan Novotný sr.
}

Fakulta sportovních studií Masarykovy univerzity

\begin{abstract}
Abstrakt
Již před dvaceti lety bylo prokázáno, že tření lyže zvyšuje teplotu sněhu. Změna skupenství na vodu umožñuje skluz lyže. Cílem této studie bylo zjistit, zda dynamická infračervená termografie je schopna zachytit rychlé změny teploty sněhu určité plochy (ne pouze v jednom bodě) lyžařské stopy před a po projetí.

Monitorovali jsme sníh ve stopě po 60 jízdách dvou běžcư různé váhy (86 a 73 kg) na dvou typech lyží a mazání (pro klasický běh a bruslení) a třemi různými rychlostmi $(3,04 \pm 0,180,3,81 \pm 0,273$ a 5,30 $\pm 0,314$ $m . s^{-1}$ ). Měrení infračerveného záření a výpočet teploty na povrchu sněhu bezprostředně před a po projetí lyžaře bylo provedeno termografickým systémem FLIR SC620 se vzorkovací frekvencí $30 \mathrm{~Hz}$.

Neparametrickým Wilcoxonovým testem pro srovnání párových hodnot bylo zjištěno významné zvýšení teploty sněhu po projetí lyži: u běžce A $z-3,71$ na -3,50 ${ }^{\circ} \mathrm{C}(p=0,000000)$ a u běžce B $z-3,75$ na $-3,50{ }^{\circ} \mathrm{C}$ $(p=0,000000)$. K návratu teploty $k$ pưvodním hodnotám dochází do 5 sekund po projetí. Byly prokázány rozdíly v zahřátí sněhu mezi běžci s různou hmotností a v prípadě použití různých typio lyží.

Studie potvrdila schopnost dynamické infračervené termografie registrovat velmi rychlé teplotní změny sněhu v určité ploše bezprostředně před a po projetí běžcư na lyžích. Plošná dynamická termografie by tak žrejmě mohla přispět $k$ volbě správné strategie a mazání lyží př̀i závodech. Je ovšem potřeba provést sérii ověrovacích studií.
\end{abstract}

\begin{abstract}
Twenty years ago it was shown that friction increases the temperature of snow skis. Change of state permits for water skis glide. The aim of this pilot study was to determine whether dynamic infrared thermography is able to capture rapid changes in temperature of snow some areas (not just at one point), the ski tracks before and after passing.

We monitored the snow on the track after 60 races two runners in various weights (86 and $73 \mathrm{~kg}$ ) on two types of skis and lubrication (for classic and skating cross) and three different speeds $(3,04 \pm 0,180$,

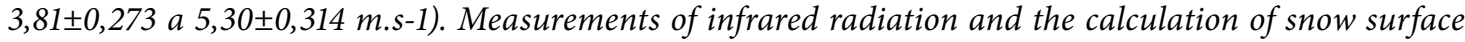
temperature immediately before and after passing skier was carried out thermo-graphic system FLIR SC620 with $30 \mathrm{Mhz}$.

Nonparametric Wilcoxon test for paired comparison of values was found significant increases in temperature after the snow cleared the skies: runner A from $-3,71$ to $-3,50{ }^{\circ} \mathrm{C}(p=0,000000)$ and runner $B$ from $-3,75 \mathrm{na}-3,50{ }^{\circ} \mathrm{C}(p=0,000000)$. To return to the baseline temperature is within 5 seconds after passing. Differences were demonstrated in the heat of snow between runners with different masses and for the use of different types of skis.

The study confirmed the ability of dynamic infrared thermography to register a very rapid temperature changes of snow in an area immediately before and after crossing the cross-country skiers. Dimensional dynamic thermography would seem to contribute to the choice of the correct strategy and lubrication in ski racing. However, it is necessary to make a series of validation studies.
\end{abstract}

Klíčová slova: $\quad$ teplota sněhu, běžecké lyžování, infračervená termografie

Key words: $\quad$ snow temperature, cross country skiing, infrared thermography 


\section{ÚVOD}

Je známo, že třením lyže se sníh ohřívá a mikroskopická vrstva vzniklé vody umožňuje skluz (Bowden et Hughes 1939), stejně tak je tomu i při tajícím ledu pod bruslí (de Koning et al. 1992, Svensson 1994, de Koning \& van Ingen Shenau 2000, Smith 2000, Gnad a Psotová 2005). Dalšími důležitými faktory jsou meteorologické podmínky, mechanické vlastnosti lyže, povrch a ošetření skluznice (Theile at al. 2009).

Změny teploty sněhu lze zjištovat různými způsoby. Starší kontaktní i bezkontaktní termometrické systémy umožňovaly měření teploty sněhu až více vteřin po průjezdu lyže a výsledky měření byly nutně zkresleny zevními faktory, které po tuto relativně dlouhou dobu na sníh působí. Novější termografické systémy, zpočátku statické, později i dynamické umožňují měřit infračervené záření (IR) určitého bodu, př́ípadně plochy.

Výsledky studia zahřívání běžeckého koberce i sněhu lyží prezentoval Roberts (1991). Bradley (2009) publikoval analogické zkušenosti s ohřevem ledu při metání koštaty v curlingu. Práce s využitím infračervené termovizní techniky v běžeckém lyžování se zabývá traumatologií (Zucco et al. 1991).

V naší pilotní studii (Studia Sportiva 2010/4, č. 2, s. 25 - 32) jsme přinesli první zkušenosti s měřením rychlých změn IR záření určitého bodu bezprostředně před a po projetí běžce na lyžích. Zjistili jsme, že dynamická termografie je schopna přinést informace o teplotních změnách $\mathrm{v}$ jednom bodu v průběhu času ve zlomcích vteřin. Tím byl překonán starší přístup detekce teplotních změn $\mathrm{z}$ jednoho termogramu, kdy bylo měřeno IR záření současně ve dvou různých bodech.

V této studii jsme se pokusili poprvé změřit IR záření a vypočítat teplotní změny určité plochy sněhu, a tím eliminovat možnou chybu vyplývající $\mathrm{z}$ měření pouze $\mathrm{v}$ jednom určitém bodě.

Cílem této studie bylo zjistit, zda metoda dynamického měření IR záření vymezené plochy sněhu je schopna:

- zjistit ohřátí sněhu po průjezdu běžce na lyžích

- rozlišit vliv různé hmotnosti, typu lyží a rychlosti jízdy na zahřátí sněhu

- a odhalit okamžik opětovného návratu teploty na výchozí hodnotu

\section{METODIKA}

Provedli jsme měření se dvěma běžci na klasických a bruslařských lyžích a třemi různými rychlostmi.

Běžec A se věnuje běžeckému lyžování velice aktivně, hlavně jako trenér biatlonistů. Druhý muž (B) se běžeckému lyžování se věnuje aktivně v průběhu zimní sezóny. Jejich věk a hmotnost uvedeny v tab. 1.

Tab. 1: Základní údaje o běžcích a délce skluznice, která byla v kontaktu se sněhem

\begin{tabular}{|c|c|c|c|c|c|c|}
\hline \multirow{2}{*}{ Běžec } & \multirow{2}{*}{$\begin{array}{l}\text { Věk } \\
(\mathrm{r})\end{array}$} & \multirow{2}{*}{$\begin{array}{l}\text { Hmotnost } \\
\text { (kg) }\end{array}$} & \multicolumn{2}{|c|}{ Šírka lyží (cm) } & \multicolumn{2}{|c|}{$\begin{array}{c}\text { Délka skluznice v kontaktu } \\
\text { se sněhem }(\mathrm{cm})\end{array}$} \\
\hline & & & $\begin{array}{c}\text { lyže pro } \\
\text { klasický běh }\end{array}$ & lyže pro bruslení & $\begin{array}{c}\text { lyže pro } \\
\text { klasický běh }\end{array}$ & lyže pro bruslení \\
\hline $\mathrm{A}$ & 54 & 86 & $4,0-4,5$ & $4,1-4,5$ & 188 & 178 \\
\hline B & 53 & 73 & $4,0-4,5$ & $4,1-4,5$ & 186 & 177 \\
\hline
\end{tabular}

Klasické lyže měly hrubou lineární strukturu a byly mazány parafinem SWIX LF 4 mimo stoupací komoru. Jako stoupací vosk jsme použili fialový klistr SWIX v jedné vrstvě. Lyže na bruslení měly také lineární hrubou strukturu s naneseným parafínem SWIX LF 4.

Měřeni proběhlo 19.2.2010 v dopoledních hodinách (10.00 - 11.30) v areálu stadionu pro běžecké lyžování u Ski hotelu v Novém Městě na Moravě za těchto povětrnostních podmínek: Zataženo s nízkou oblačností, mrznoucí mrholení. Ostatní zevní podmínky viz tab. 2. Stopa ve sněhu byla vyfrézovaná z předchozího večera, zmrzlý sníh. 
Tab. 2: Venkovní klimatické podmínky v průběhu měření

\begin{tabular}{|c|c|c|c|}
\hline $\begin{array}{c}\text { Výška nad sněhem } \\
(\mathrm{m})\end{array}$ & $\begin{array}{c}\text { Teplota } \\
\left({ }^{\circ} \mathrm{C}\right)\end{array}$ & $\begin{array}{c}\text { Relativní vlhkost } \\
(\%)\end{array}$ & $\begin{array}{c}\text { Rychlost větru } \\
(\mathrm{m} / \mathrm{s})\end{array}$ \\
\hline 0,02 & $-0,2$ & 100 & 2,4 \\
\hline 1,5 & $-0,2$ & 100 & 3,8 \\
\hline
\end{tabular}

Oba běžci jeli z mírného svahu ze tří různých vzdáleností, a tím dosahovali 3 různých rychlostí. $\mathrm{Z}$ každé této pozice jeli $5 \mathrm{x}$. Sledovali jsme levou i pravou stopu. Po absolvování těchto průjezdů s lyžemi na bruslení se přezuli do klasických lyží a celé měření se opakovalo. Každý běžec tedy projel 15x na bruslařských a 15x na klasických lyžích. Celkem jsme natočili 60 videosekvencí. Levou i pravou stopu jsme hodnotili zvlášt', vypočetli jsme tedy průměrnou teplotu určité plochy sněhu bezprostředně před a po, $5 \mathrm{~s}$ a 10 s po projetí běžce (tj. předpokládali jsme celkem 240 výpočtů).

Infračervené záření bylo snímáno a výpočet teploty prováděn infračervenou termografickou kamerou FLIR SC620 (obr. 1): Teplotní citlivost $0.065^{\circ} \mathrm{C}$ ve $30^{\circ} \mathrm{C}$, spektrální rozsah 7,5 - $13 \mu \mathrm{m}$, teplotní rozsah -40 až $+120^{\circ} \mathrm{C}$, přesnost stanovení teploty $\pm 2^{\circ} \mathrm{C}$, obrazové rozlišení $640 x 480$ pixelů. Snímkovací frekvence byla $30 \mathrm{~Hz}$. Pro on-line přenos sekvencí obrazů do laptopu Philips bylo využito spojení firewire.

Při měření byla kamera upevněna na stativu $1,5 \mathrm{~m}$ nad úrovní běžecké stopy, mírně šikmo - $\mathrm{s}$ úhlem 20-30 od svislice, aby kamera se stativem nebránila průjezdu běžce. Současně bylo umístění kamery voleno tak, aby sníh neodrážel jiné zdroje infračerveného záření, které by mohlo zásadně zkreslit výsledky, jak se o tom zmiňuje např. Honner (2004).

Ke zpracování sekvencí snímků jsme použili software ThermaCAM Researcher Professional 2.9 (obr. 2). Po drobné, ale velice důležité úpravě v údajích o emisivitě sněhu $(0,85)$, teplotě vzduchu, vlhkosti a dalších faktorech, byla stanovena statická pole v podobě čtverce o straně $4 \mathrm{~cm}$, kterou byla šíře stopy po projetí lyže. Rychlost pohybu lyže byla vypočtena z časů, za které projede celá lyže v místě bodu měření.

V programu Statistika CZ 9.0 byl, po zamítnutí hypotézy o normálním rozložení hodnot (ShapiroWilksův W test), proveden neparametrický Wilcoxonův test rozdílu teplot před a po projetí lyží, zvlášt u každého běžce a zvlášt u klasických a bruslařských lyží. Stejným testem byly posuzovány spárované hodnoty rozdílů teplot při různých třech rychlostech jízdy. Dále byl proveden Mann-Whitneyův U test rozdílu mezi dvěma lyžaři a dvěma typy lyží. Pro celkové posouzení rozdílů zahřátí sněhu pod vlivem pohybu lyží byl použit také neparametrický vícenásobný Friedmanův (ANOVA) test rozdílu. Pro posouzení rozdílů mezi zahřátím sněhu při různých rychlostech jízdy byl použit (rovněž neparametrický) vícenásobný Kruskal-Wallisův test.

K prezentaci a interpretaci výsledků posloužily grafy programu Statistika.

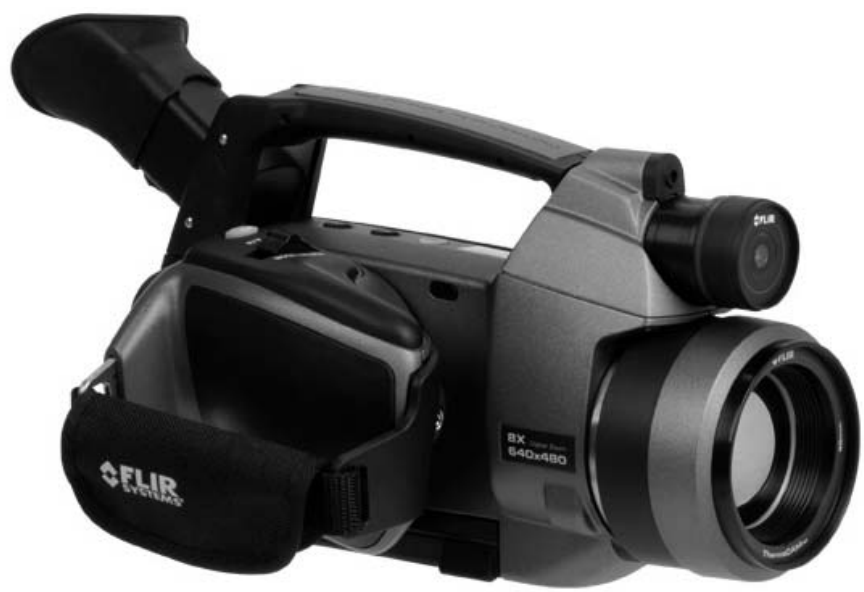

Obr. 1: Infračervená termografická kamera FLIR SC 620 


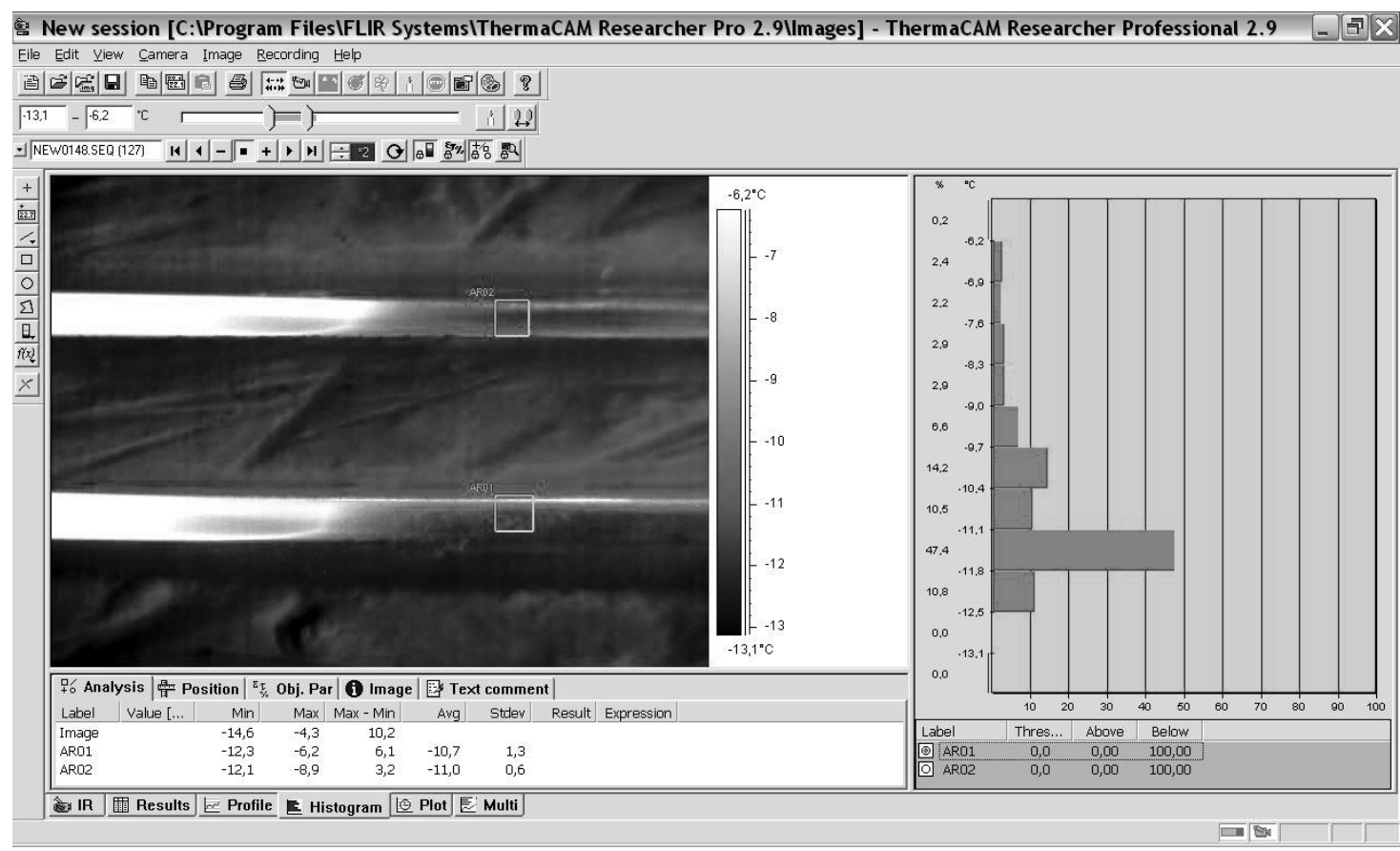

Obr. 2: Ukázka ze zpracování dat (označení ploch na stopě) v programu ThermalCAM Researcher Professional 2.9

\section{VÝSLEDKY}

Ze základních výsledků vybíráme a předkládáme jako př́íklad teploty sněhu před, po, 5 a 10 sekund po projetí a rozdíly teplot před a po projetí běžce A, na lyžích pro bruslení druhou rychlostí (tab. 3).

Tab. 3: Rychlost a teploty sněhu ve stopě běžce A, na lyžích pro bruslení, druhou rychlostí

\begin{tabular}{|c|c|c|c|c|c|c|}
\hline \multirow[t]{2}{*}{ Číslo jízdy } & \multirow{2}{*}{$\begin{array}{l}\text { Rychlost } \\
\left(\mathrm{m} \cdot \mathrm{s}^{-1}\right)\end{array}$} & \multicolumn{4}{|c|}{ Teplota sněhu $\left({ }^{\circ} \mathrm{C}\right)$} & \multirow{2}{*}{$\begin{array}{c}\begin{array}{c}\text { Rozdíl } \\
\text { teplot }\left({ }^{\circ} \mathrm{C}\right)\end{array} \\
\text { před-po } \\
\end{array}$} \\
\hline & & před & po & $5 \mathrm{~s} \mathrm{po}$ & $10 \mathrm{~s}$ po & \\
\hline 1 & 3,77 & $-3,9$ & $-3,6$ & $-3,9$ & $-3,9$ & 0,3 \\
\hline 2 & 3,78 & -4 & $-3,7$ & $-3,9$ & -4 & 0,3 \\
\hline 3 & 3,78 & $-3,6$ & $-3,4$ & $-3,5$ & $-3,6$ & 0,2 \\
\hline 4 & 3,78 & $-3,6$ & $-3,3$ & $-3,5$ & $-3,5$ & 0,3 \\
\hline 5 & 3,77 & $-3,6$ & $-3,4$ & $-3,6$ & $-3,6$ & 0,2 \\
\hline $\mathrm{x}$ & 3,776 & $-3,74$ & $-3,48$ & $-3,68$ & $-3,72$ & 0,26 \\
\hline$s$ & 0,0055 & 0,195 & 0,164 & 0,205 & 0,217 & 0,0548 \\
\hline medián & 3,78 & $-3,6$ & $-3,4$ & $-3,6$ & $-3,6$ & 0,3 \\
\hline
\end{tabular}

Vysvětlivky: $\mathrm{x}$ - průměr, s - směrodatná odchylka

Některé hodnoty nebylo možné vypočítat kvůli „mrtvým“ obrázkům (3), které vznikly ve chvíli, kdy proběhla automatická kalibrace kamery, uzavření závěrky. U několika průjezdů jsme zastavili kameru předčasně, a proto jsme nebyli schopni vypočítat hodnotu „po 10 s“ po projetí lyže (6).

Výsledky Wilcoxonova testu dokládají významné rozdíly vypočtených teplot bezprostředně před a po projetí lyží, jak u klasických, tak u bruslařských (tab. 4 a 5). 
Tab. 4: Výsledky Wilcoxonova testu rozdílu teplot $\left({ }^{\circ} \mathrm{C}\right)$ bezprostředně před a po projetí dvou běžců

\begin{tabular}{|c|c|c|c|c|c|c|c|c|c|}
\hline \multirow{2}{*}{ Běžec } & \multirow{2}{*}{$\mathrm{n}$} & \multicolumn{3}{|c|}{ Před } & \multicolumn{3}{|c|}{ Po } & \multirow{2}{*}{$\mathrm{T}$} & \multirow{2}{*}{$\mathrm{p}$} \\
\hline & & $\mathrm{m}_{\mathrm{e}}$ & $\mathrm{Q}_{10}$ & $\mathrm{Q}_{90}$ & $\mathrm{~m}_{\mathrm{e}}$ & $\mathrm{Q}_{10}$ & $\mathrm{Q}_{90}$ & & \\
\hline A & 60 & $-3,75$ & $-3,95$ & $-3,45$ & $-3,50$ & $-3,75$ & $-3,20$ & 4,500 & 0,000000 \\
\hline B & 58 & $-3,75$ & $-4,00$ & $-3,40$ & $-3,50$ & $-3,70$ & $-3,20$ & 0,000 & 0,000000 \\
\hline
\end{tabular}

Vysvětlivky: $\mathrm{n}$ - počet měření, $\mathrm{m}_{\mathrm{e}}-$ medián, $\mathrm{Q}_{10}-10$. percentil, $\mathrm{Q}_{90}-90$. percentil, $\mathrm{T}$ - testovací charakteristika, $\mathrm{p}$ - hladina významnosti.

Tab. 5: Výsledky Wilcoxonova testu rozdílu teplot $\left({ }^{\circ} \mathrm{C}\right)$ bezprostředně před a po projetí dvěma různými typy lyží

\begin{tabular}{|c|c|c|c|c|c|c|c|c|c|}
\hline \multirow{2}{*}{ Lyže pro } & \multirow{2}{*}{$\mathrm{n}$} & \multicolumn{3}{|c|}{ Před } & \multicolumn{3}{|c|}{ Po } & \multirow{2}{*}{$\mathrm{U}$} & \multirow{2}{*}{$\mathrm{p}$} \\
\hline & & $\mathrm{m}_{\mathrm{e}}$ & $\mathrm{Q}_{10}$ & $\mathrm{Q}_{90}$ & $\mathrm{~m}_{\mathrm{e}}$ & $\mathrm{Q}_{10}$ & $\mathrm{Q}_{90}$ & & \\
\hline $\begin{array}{c}\text { klasický } \\
\text { běh }\end{array}$ & 60 & $-3,65$ & $-3,90$ & $-3,45$ & $-3,50$ & $-3,70$ & $-3,30$ & 0,000 & 0,000000 \\
\hline bruslení & 58 & $-3,80$ & $-4,10$ & $-3,30$ & $-3,50$ & $-3,90$ & $-3,10$ & 2,000 & 0,000000 \\
\hline
\end{tabular}

Vysvětlivky: $\mathrm{n}$ - počet měření, $\mathrm{m}_{\mathrm{e}}-$ medián, $\mathrm{Q}_{10}-10$. percentil, $\mathrm{Q}_{90}-90$. percentil, $\mathrm{U}$ - testovací charakteristika, $\mathrm{p}$ - hladina významnosti.

Výsledkem Mann-Whitneyova U testu dokládáme významný rozdíl v zahřátí sněhu mezi oběma běžci (s rozdílnou hmotností) i mezi dvěma typy lyží (tab. 6).

Tab. 6: Rozdíly teplot sněhu $\left({ }^{\circ} \mathrm{C}\right)$ bezprostředně před a po projetí dvou běžců $(\mathrm{A}$ a $\mathrm{B}) \mathrm{s}$ různou hmotností a dvěma typy lyží ( $\mathrm{n}=58)$, jejich srovnání Mann-Whitneyovým U testem

\begin{tabular}{|c|c|c|c|c|c|c|}
\hline \multicolumn{2}{|c|}{} & $\mathrm{m}_{\mathrm{e}}$ & $\mathrm{Q}_{10}$ & $\mathrm{Q}_{90}$ & $\mathrm{U}$ & $\mathrm{p}$ \\
\hline \multirow{3}{*}{ Běžci } & $\mathrm{A}(86 \mathrm{~kg})$ & 0,200 & 0,150 & 0,300 & \multirow{2}{*}{378,5} & \multirow{2}{*}{0,021930} \\
\cline { 2 - 5 } & $\mathrm{B}(73 \mathrm{~kg})$ & 0,200 & 0,100 & 0,300 & & \\
\hline \multirow{2}{*}{ Lyže pro } & klasický běh & 0,200 & 0,100 & 0,300 & \multirow{2}{*}{385,5} & \multirow{2}{*}{0,021884} \\
\cline { 2 - 6 } & bruslení & 0,200 & 0,200 & 0,300 & & \\
\hline
\end{tabular}

Vysvětlivky: $\mathrm{m}_{\mathrm{e}}-$ medián, $\mathrm{Q}_{10}-10$. percentil, $\mathrm{Q}_{90}-90$. percentil, $\mathrm{U}$ - testovací charakteristika, $\mathrm{p}-\mathrm{hla}-$ dina významnosti.

Dynamiku teplotních změn dokumentujeme na vybraných případech měření při nejvyšší rychlosti jízdy $\left(5,3 \mathrm{~m} \cdot \mathrm{s}^{-1}\right)$. Výsledky jsou rozděleny zvlášt pro lyžaře $\mathrm{A}$ a $\mathrm{B}$ a současně pro lyže pro klasický běh a pro bruslení (Grafy 1-4). Prostřednictvím mnohonásobného Friedmanova testu zamítáme hypotézu o shodě teplot ve všech těchto čtyřech uvedených př́padech $(p \leq 0,0007 ; n=10)$. Z tohoto faktu vyplývá, že zvýšení teploty sněhu bezprostředně po projetí lyže je významné.

Spojnicové grafy odhalují nárůst a pokles teplot v průběhu času u klasických a bruslařských lyží bezprostředně před, po a 5 a 10 sekund po projetí běžce A (graf 1 a 2) a B (graf 3 a 4) nejvyšší rychlostí. Z grafư je také zř̌etelné, že návratu teploty k původní teplotě je dosaženo prakticky do 5 sekund po projetí. 
Graf 1: Teploty sněhu levé stopy před a po projetí běžce A na lyžích pro klasický běh

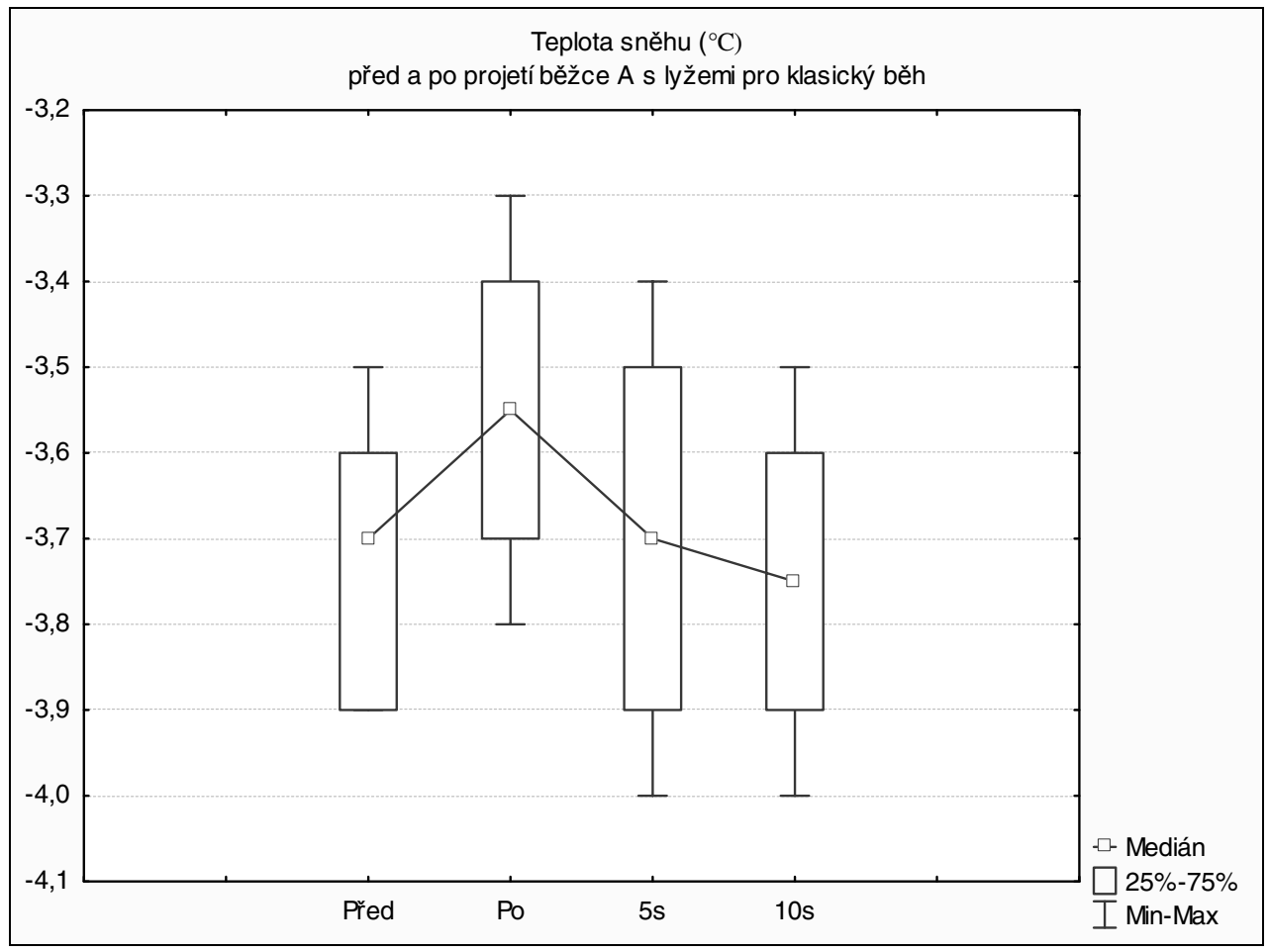

Graf 2: Teploty sněhu levé stopy před a po projetí běžce A na lyžích pro bruslení

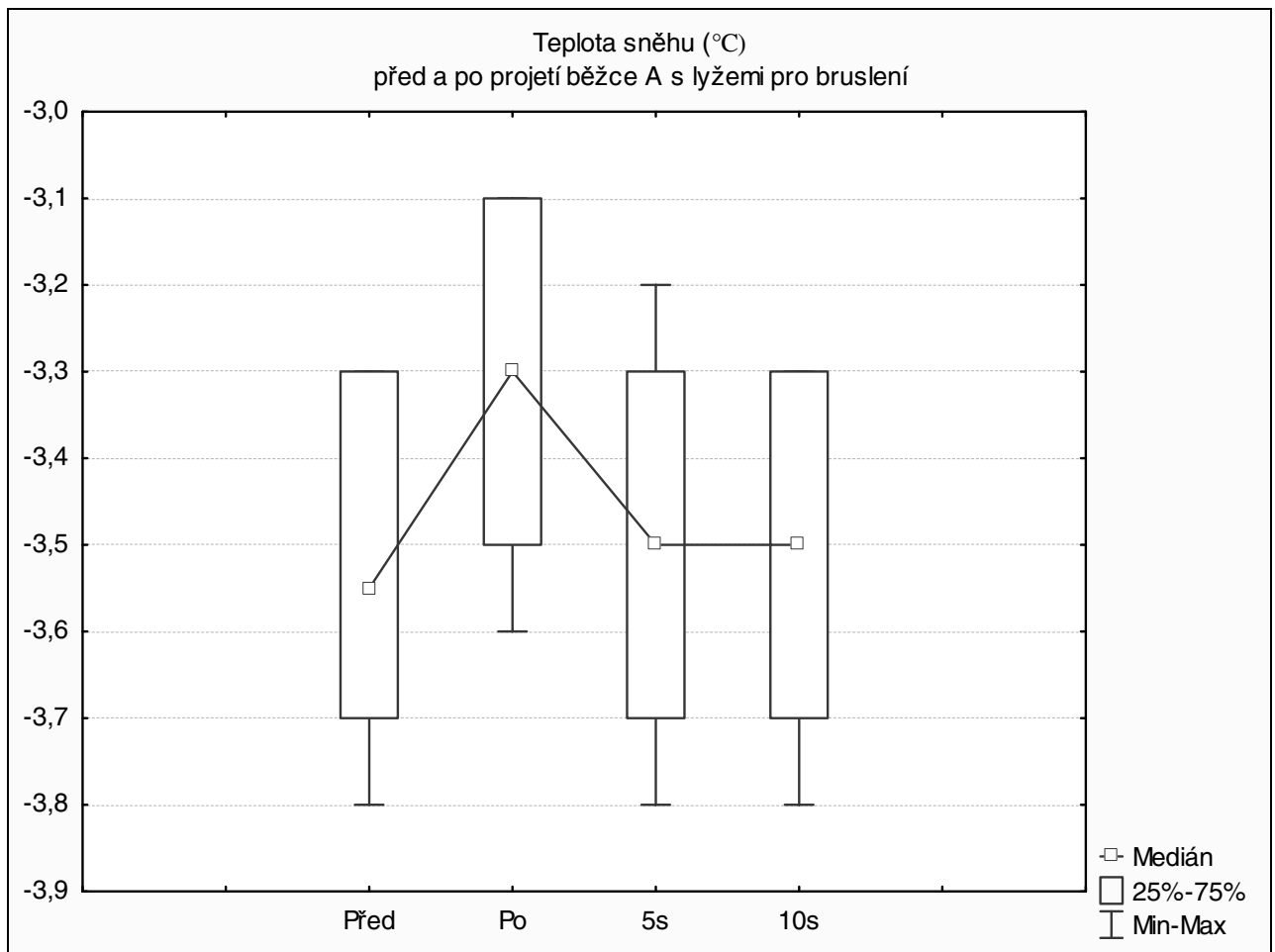


Graf 3: Teploty sněhu levé stopy před a po projetí běžce B na lyžích pro klasický běh

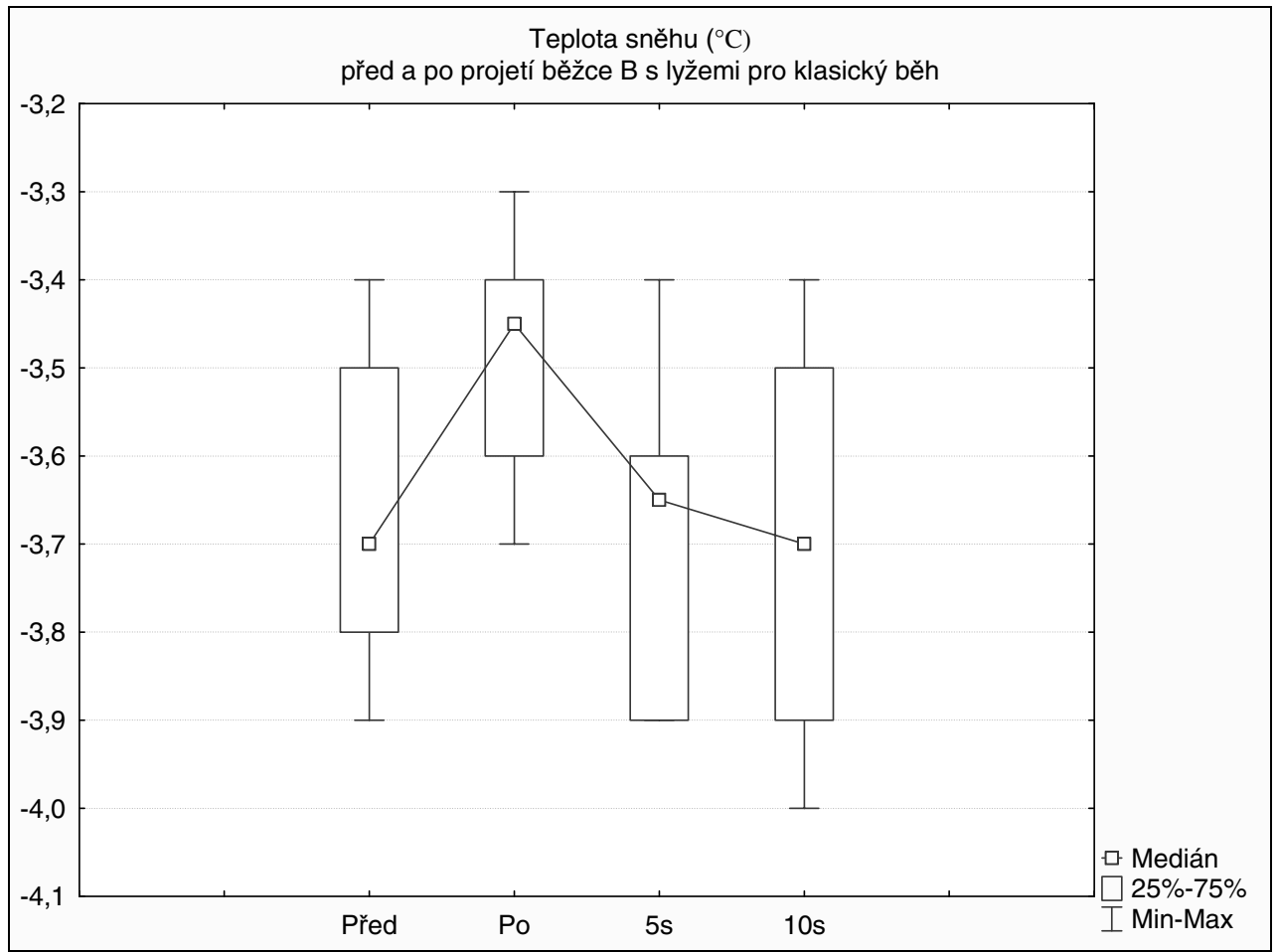

Graf 4: Teploty sněhu levé stopy před a po projetí běžce B na lyžích pro bruslení

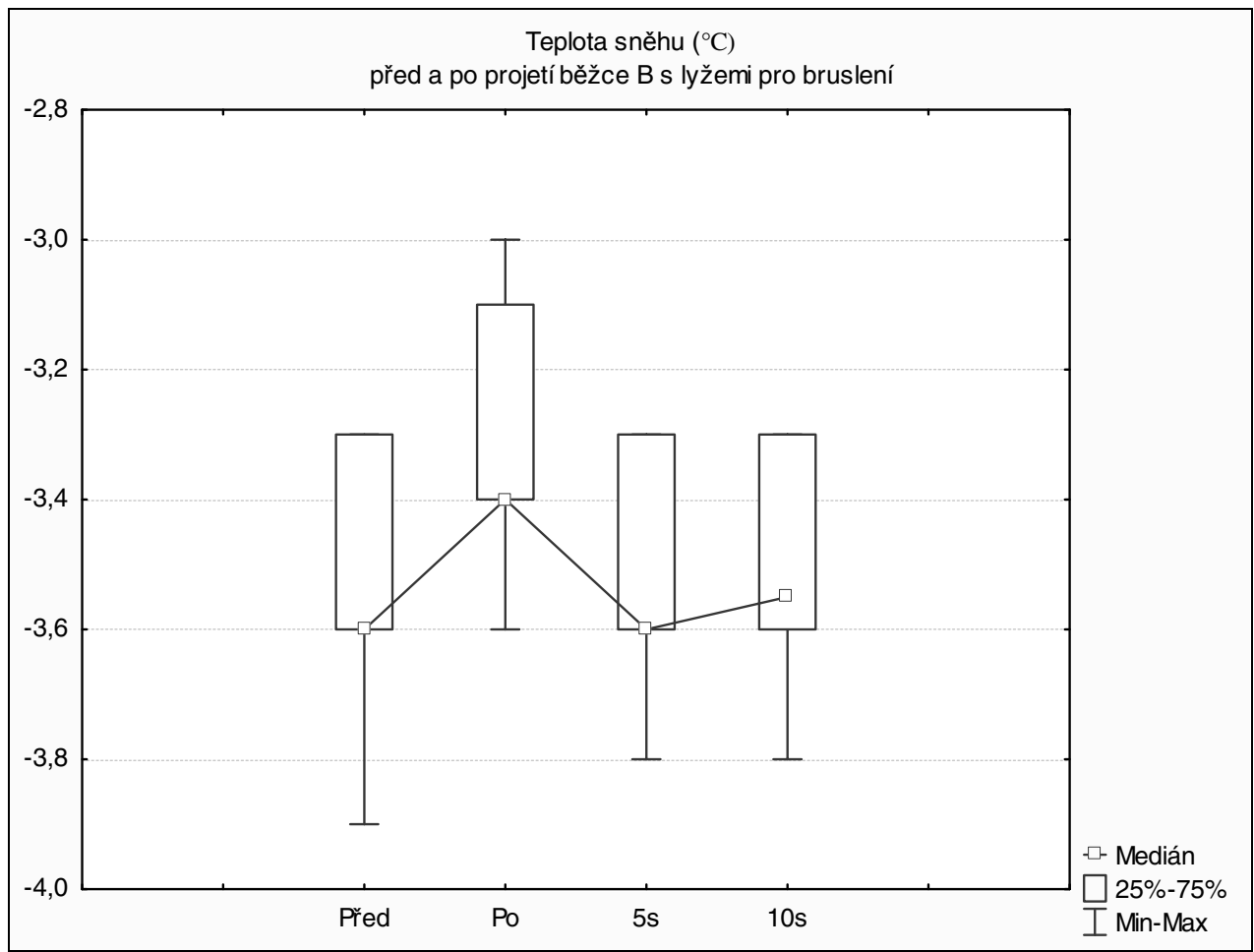


Pro lepší představu o zahřátí sněhu při různých rychlostech jízdy (tab.7) prezentujeme graf 5 .

Graf 5: Rozdíly teplot $\left({ }^{\circ} \mathrm{C}\right)$ bezprostředně před a po projetí př̀i třech různých rychlostech $(\mathrm{V} 1, \mathrm{~V} 2, \mathrm{~V} 3$ tab.7; $\mathrm{n}=3 \times 40)$

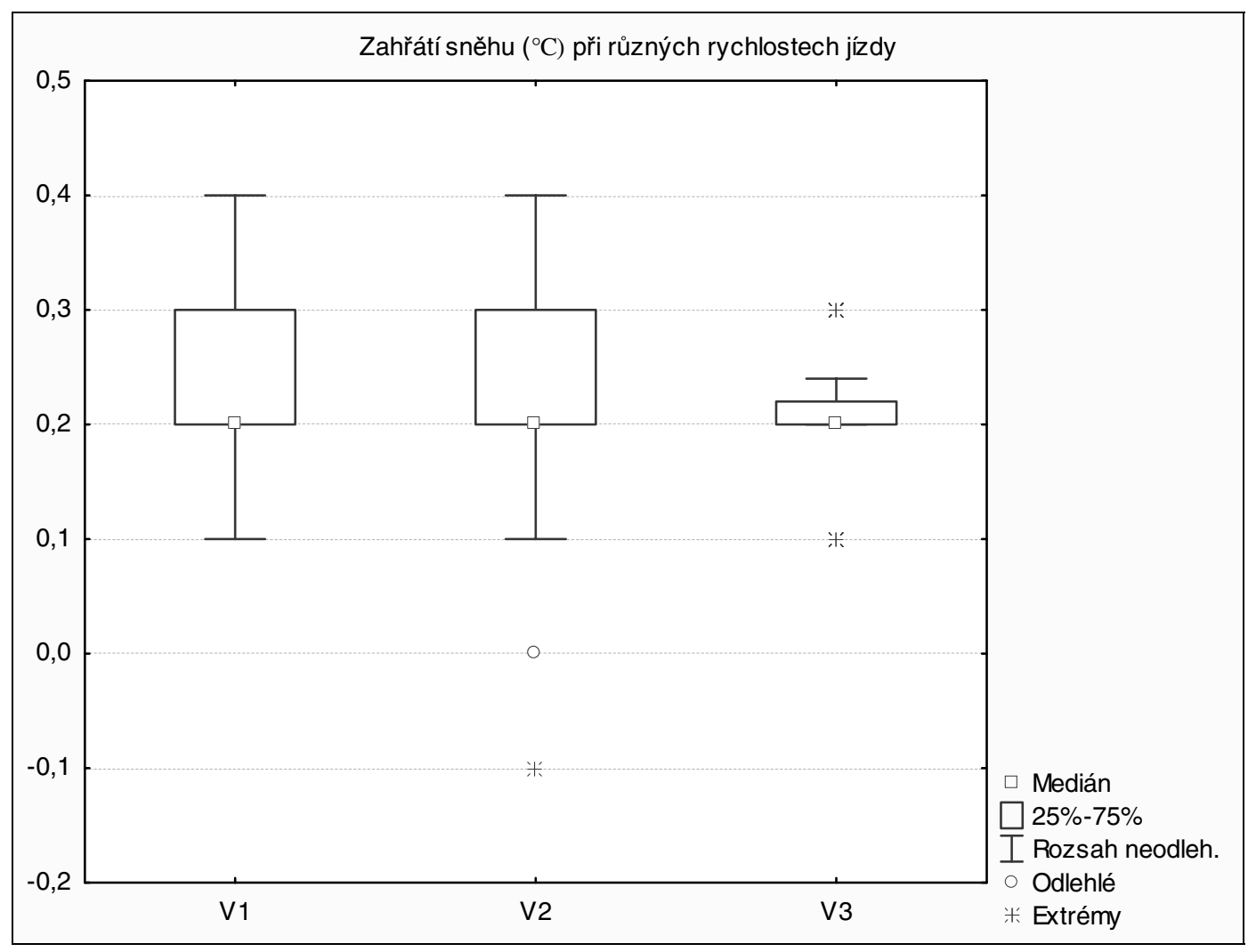

Výsledek vícenásobného Kruskal-Wallisova testu rozdílů zahřátí sněhu při různých rychlostech (tab.7), společně pro oba běžce i oba typy lyží (testovací charakteristika H je 1,6795 a hladina významnosti p 0,4318), neopravňuje zamítnout hypotézu o shodě.

Pro úplnost také dokládáme významné rozdíly mezi třemi rychlostmi jízdy (mezi V1 a V2, V2 a V3, V1 a V3): Testovací charakteristiky Mann-Whitneyova U testu (U) jsou 32,00, 0,00 a 0,00; a všechny hladiny významnosti (p) jsou 0,000000 .

Tab.7: Rychlosti jízdy

\begin{tabular}{|c|c|}
\hline \multicolumn{2}{|c|}{ Rychlost $\left(\mathrm{x} \pm \mathrm{s}, \mathrm{m} . \mathrm{s}^{-1}\right)$} \\
\hline V1 $(\mathrm{n}=36)$ & $3,04 \pm 0,180$ \\
\hline V2 $(\mathrm{n}=38)$ & $3,81 \pm 0,273$ \\
\hline V3 $(\mathrm{n}=40)$ & $5,30 \pm 0,314$ \\
\hline
\end{tabular}

\section{DISKUZE}

$\mathrm{Z}$ našeho měření můžeme usuzovat, že projetí jednoho běžce rychlostí přibližně 3 až $5,3 \mathrm{~m} \cdot \mathrm{s}^{-1}$ zahřeje sníh bezprostředně po projetí, ale po 5 a více vteřinách se již teplota vrací k původní hodnotě, a pak již nemá význam pro ostatní závodníky, kteří přijedou do stopy. 
Naše výsledky lze částečně srovnat s ojedinělou prací Robertse (1991), který počítal teplotu sněhu v blízkosti lyží při sjezdu ze svahu (sklon asi $10^{\circ}$, teplota sněhu $-5,0^{\circ} \mathrm{C}$ ) pomocí termografického systému. $\mathrm{V}$ této studii zjistili vyšší teplotu sněhu ve stopě po projetí lyže přibližně o $0,3^{\circ} \mathrm{C}$, což je mírně více než v naší studii. Šlo však o sjezdové lyže a nižší rychlost (kolem $\left.1 \mathrm{~m} \cdot \mathrm{s}^{-1}\right)$. Nevýhodou jejich metodiky je, že nepočítali teplotu ve stejném bodě před a po projetí lyže. Tento nedostatek eliminujeme měřením v identické ploše před a po projetí lyže. Vysoké riziko chyby výsledku Robertsovy studie nese fakt, že měřili radiaci v bodech, respektive na prímce, ve které teplota bod po bodu značně oscilovala $\left(0,6 \mathrm{až} 1,2^{\circ} \mathrm{C}\right)$. Riziko této chyby minimalizujeme měřením IR záření a výpočtem průměrné teploty $\mathrm{z}$ vymezené plochy, ne bodu.

Problémem při měření byla automatická kalibrace kamery, při níž vznikají „hluchá“ místa; tuto funkci lze vypnout. Na druhou stranu by se mohlo stát, že obraz by nebyl plně zaostřen, automatická kalibrace má svoji funkci určitě opodstatněnou. Detailnější výpočty by usnadnila infračervená termovizní kamera s vyšší frekvencí než $30 \mathrm{~Hz}$, která by nám zaručila ostřejší jednotlivé obrázky v jednotlivých sekvencích.

Pro prrímý pohled na obě stopy by bylo lepší umístit kameru na nějaký můstek či konstrukci přímo nad měřenými objekty - závodníky.

Je důležité vždy dbát na všechny meteorologické podmínky a další hodnoty faktorů, které se zadávají do výpočetních programů. $\mathrm{V}$ nedbalosti se můžeme dopustit docela odlišných výsledků.

Bylo by dobré pokračovat $\mathrm{v}$ dalších měřeních, ale se skupinou běžců při ostrých závodech nebo alespoň s co nejbližší simulací v tréninku - větší počet závodníků při jejich závodní rychlosti. Rychlost běžců v ostrém závodě je vyšší, než rychlosti při našem měření. Za úvahu stojí také výzkum celé skupiny běžců $\mathrm{v}$ různých terénech a kvalitě sněhu, materiálu a ošetření skluznic.

K dosažení statisticky významnějších výsledků by př́ípadná další studie jednotlivých běžců či celé skupiny měla mít menší počet nezávislých proměnných a větší počet měření.

\section{ZÁVĚRY}

Výsledky analýzy sekvencí dynamických termogramů sněhu v běžecké stopě ukazují na:

- zřetelné zahřátí sněhu ve stopě po projetí jednoho běžce

- nepatrně vyšší rozdíl teplot, který dosáhl běžec lehčí o $13 \mathrm{~kg}$

- vyšší zahřátí sněhu u bruslařských lyží než u lyží na klasický způsob běhu

- vrácení teploty sněhu do původních hodnot do 5 sekund po projetí běžce

- nevýznamné rozdíly $\mathrm{v}$ zahřátí sněhu př̀i různé rychlosti jízdy mezi 3 a 5,3 m.s $\mathrm{s}^{-1}$

Výsledky prokazují schopnost dynamické termografie zjistit:

- teplotní změny z určité plochy sněhové stopy, a tím dávají možnost vyhnout se chybám, které vyplývají $z$ měření jednoho bodu

- IR záření sněhu v průběhu času, po který se mění podmínky jako ve skutečném závodě nebo tréninku. Jde o kvalitativně vyšší úroveň než analýza z jediného statického snímku

Pro další výzkum doporučujeme:

- $\quad$ vypnutí automatické kalibrace, umístění kamery nad stopu a běžce

- $\quad$ zkoumat teplotní změny při průjezdu skupiny běžců, při závodních rychlostech, v různých terénech a kvalitách sněhu, při použití různých materiálů a mazaní skluznic lyží

\section{Literatura}

BOWDEN, F.P.; HUGHES, T.P. The mechanism of sliding on ice and snow. Proc. R. Soc. Lond. Math. Phys. Sci. 1939, 172 A, pp. 280-298. (In: Theile T.,Szabo D., Luthi A, Rhyner H., Schneebeli M. Mechanics of the Ski-Snow Contact. Tribol Lett, 2009, 36, pp. 223-231.)

BRADLEY, J.L. The sports science of curling: A practical review. Journal of Sports Science and Medicine, 2009, 8, pp. 495-500. 
GNAD, T .; PSOTOVÁ, D. Běh na lyžích. Karolinum, Praha, 2005, 151 s.

HONNER, M. Infračervená kvantivativní termografie ve výzkumu fyzikálních technologií. Habilitační práce. Západočeská univerzita, Plzeň, 2004, $166 \mathrm{~s}$.

de KONING, J.J.; de GROOT, G; van INGEN SCHENAU, G.J. Ice friction during speed skating. Journal of Biomechanics, 25, 8, 1992, pp. 565-571.

de KONING, J.J.; van INGEN SCHENAU, G.J. Performance-determining factors in speed skating. Biomechanics in sport. V.M.Zatsiorsky, ed., Oxford, Blackwell Science, 2000, 232-246. (In: Zatsiorsky, V.M. Kinetics of Human Motion. Human Kinetics, Champaign, 2002, pp. 86-88.)

NOVOTNÝ, J. Infračervená termografie ve sportovní medicíně. In Studia Sportiva, 2009, 3, 1, s. 33-42.

ROBERTS, Ch.C. Infrared thermographic analysis of snow ski tracks. Proc. SPIE ssVol. 1467, 1991: pp. 207-218, Thermosense XIII, George S. Baird; Ed. Dostupné na internetu: <http://www.robertsski.com/ webpgss/skitrk.htm; 16.2.2010>

SMITH, G.A. Cross-country skiing: Technique, equipment and enviromental factors affecting performance. Biomechanics in sport. V.M.Zatsiorsky, ed., Oxford, Blackwell Science, 2000, 247-270. (In: Zatsiorsky, V.M. Kinetics of Human Motion. Human Kinetics, Champaign, 2002, pp. 86-88.)

SOUMAR, L.; BOLEK, E. Běh na lyžích, Grada Publishing, Praha, 2001, 130 s.

SVENSSON, E. Ski Skating With Champions, How to Ski With Least Energy. Dynagraphics, Portland, 1994, $272 \mathrm{pp}$.

THEILE, T.; SZABO, D.; LUTHI, A.; RHYNER, H.; SCHNEEBELI, M. Mechanics of the Ski-Snow Contact. Tribol Lett, 2009, 36, pp. 223-231.

ZUCCO P.; MOTE C.D.jr.; JOHNSON R.J.: Ski boot thermography method and its significance. In Skiing trauma and safety, Eighth international symposium. ASTM International, 1991, pp. 208-213. Dostupné na internetu <http://books.google.cz/books?id=IdhI0peNJCUC\&pg=PA208\&lpg=PA208\&dq=thermog raphy+skiing\&source $=$ bl\&ots $=$ L42NUlfPEL\&sig $=4 \mathrm{dkBlzo5Fz} 0 \mathrm{v} 1 \mathrm{xGYJcEScx} 6 \mathrm{gSg} \& \mathrm{hl}=\mathrm{cs} \& \mathrm{ei}=2 \mathrm{~S} \_\mathrm{xS} 9$ bbFZLcmgO165jvCw\&sa=X\&oi=book_result\&ct=result\&resnum $=1 \&$ ved $=0 \mathrm{CB} 0 \mathrm{Q} 6 \mathrm{AEwAA} \# \mathrm{v}=$ onepage $\& \mathrm{q}=$ thermography\%20skiing\&f=false $>$ 